\title{
molecules
}

ISSN 1420-3049

http://www.mdpi.org

\section{Chemical Constituents of Piper betle Linn. (Piperaceae) roots}

\author{
K. Ghosh * and T. K. Bhattacharya \\ Department of Chemical Technology, University College of Science \& Technology, Calcutta \\ University, Kolkata-700 009, India.
}

Author to whom correspondence should be addressed; E-mail: keshab g@yahoo.com; Tel. (+91)-0332350-8386, Fax (+91)-033-2351-9755.

Received: 28 May 2004; in revised form: 28 December 2004 / Accepted: 7 January 2005 / Published: 31 August 2005

\begin{abstract}
Column chromatography of the alcoholic extract of Piper betle roots furnished aristololactam A-II and a new phenyl propene, characterized as 4-allyl resorcinol, while the petroleum-ether extract yielded a diketosteroid, viz. stigmast-4-en-3,6-dione. All these compounds were characterized by spectroscopic means. Isolation of these compounds from this source is being reported here for the first time.
\end{abstract}

Keywords: Piper betle, Piperaceae, phenyl propene, diketosteroid, aristololactam A-II.

\section{Introduction}

Piper betle Linn. (Piperaceae) is a perennial dioecious creeper, probably native of Malaysia but cultivated in India for its leaves, used for chewing [1]. The leaf is carminative, aphrodisiac, tonic, laxative and improves appetite [2]. Leaves contained caryophyllene, cadinene, $\gamma$-lactone, allyl catechol, $p$-cymene and eugenol methyl ether in varying amounts $[3,4]$. The alcoholic extract of the leaf-stalk showed significant antifertility effects in both male and female rats [5-7]. Recently, cepharadione A, dotriacontanoic acid and tritriacontane were reported to be isolated from the petrol extract of leaves; piperine and piperlonguminine from petrol + dichloromethane extract of stems and $\beta$-sitosteryl palmitate from petrol + dichloromethane extract of root parts of $P$. betle [8]. In another study, the roots were found to contain $3 \beta$-acetyl ursolic acid and ursonic acid [9]. Traditionally, the roots of $P$. betle mixed with black pepper were said to be used as a contraceptive by women [10]. To elucidate and confirm the veracity of folklore antifertility claims, we report herein the further investigation of the constituents of $P$. betle roots. 


\section{Results and Discussion}

Si gel column chromatography of the petroleum ether extract furnished stearic acid and $\beta$-sitosterol from petroleum ether-benzene eluates and a diketosteroid, viz. stigmast-4-en-3,6-dione (1) from the benzene eluates. Compound 1 gave a negative Liebermann-Burchard test for sterols. Its IR spectrum showed an absorption band at $1675 \mathrm{~cm}^{-1}$, attributed to an $\alpha, \beta$-unsaturated ketone. The ${ }^{1} \mathrm{H}-\mathrm{NMR}$ spectrum showed a singlet at $\delta 6.17$, attributed to the proton at the C-4 position flanked by two $\alpha, \beta$ unsaturated ketones. This was consistent with literature values [11] and its identity was further confirmed by comparing it (UV, IR and TLC) with the oxidation product of $\beta$-sitosterol with Jones reagent. The subsequent alcoholic extract was further resolved into ethyl acetate and $n$-butanol extracts. Column chromatography of the ethyl acetate extract yielded 4-allyl resorcinol (2) from petroleum ether-benzene eluates and aristololactam A-II (3) from chloroform eluates. The identity of 3 was confirmed by comparing the reported ${ }^{1} \mathrm{H}-\mathrm{NMR}$ data with those given in the literature [12] and also by direct comparison with an authentic sample. Isolation of compound $\mathbf{3}$ from the family Piperaceae has not been reported so far [8], although this basic skeleton has been isolated from Menispermaceae [13], Papaveraceae [14] and Aristolochiaceae [15].
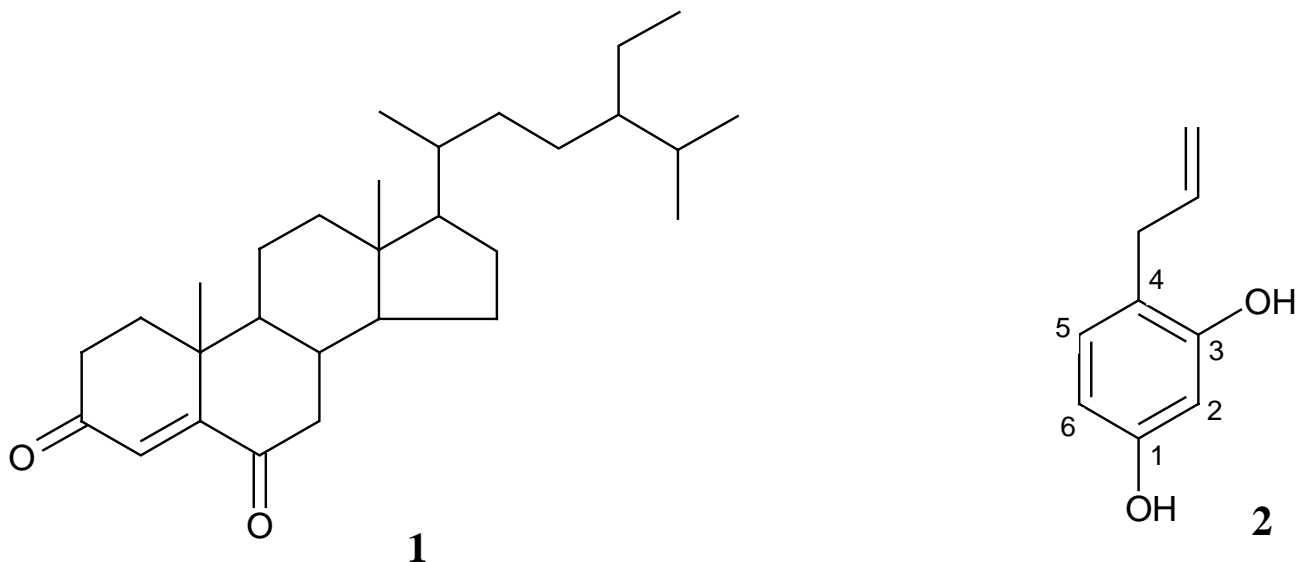

1<smiles>COc1c(O)cc2c3c(cc4ccccc4c13)NC2=O</smiles>

Compound 2 possessed a characteristic phenolic odour and gave a bluish-black colouration with $\mathrm{FeCl}_{3}$. Its ${ }^{1} \mathrm{H}-\mathrm{NMR}$ spectrum showed several peaks at $\delta 3.25(2 \mathrm{H}, \mathrm{d}, J=9 \mathrm{~Hz}), 5.05(2 \mathrm{H}, \mathrm{m})$ and 5.91 $(1 \mathrm{H}, \mathrm{m})$, characteristic of protons of an allyl moiety and other peaks at $\delta 6.61(1 \mathrm{H}, \mathrm{dd}, J=9,1.8 \mathrm{~Hz})$, $6.70(1 \mathrm{H}, \mathrm{d}, J=1.8 \mathrm{~Hz})$ and $6.78(1 \mathrm{H}, \mathrm{d}, J=9 \mathrm{~Hz})$, indicative of protons of a 1,3,4-trisubstituted benzene. The mass spectrum of 4-allyl resorcinol is also consistent with the proposed structure 2 . This is the first naturally occurring phenyl propene of all the compounds isolated so far from $P$. betle roots. 


\section{Conclusions}

The present study provides the first report on the occurrence of 4-allyl resorcinol, stigmast-4-en3,6-dione and aristololactam A-II in Piper species. As a phenanthrene alkaloid has previously been shown to possess encouraging antifertility effects [16], the antifertility properties assigned to Piper betle roots in folklore may be due to this last active component or to the crude alcoholic extract.

\section{Acknowledgements}

We are grateful to C.S.I.R., New Delhi for granting a fellowship (SRF) to K. Ghosh. We are indebted to Indian Institute of Chemical Biology (I.I.C.B.), Kolkata, India for recording NMR and MS.

\section{Experimental}

\section{General}

Column chromatographic separation of compounds from the crude extracts was carried out using Si gel (60-120 mesh, Qualigens Fine Chemicals). Petroleum ether (Pet. ether) refers to the fraction of boiling range $60-80^{\circ} \mathrm{C}$. Melting points were determined in open capillaries in an electrical metal bath and are uncorrected. IR spectra were recorded using a RXI-FT-IR Perkin-Elmer spectrophotometer. ${ }^{1} \mathrm{H}-\mathrm{NMR}$ (300 MHz) were recorded on a Bruker DPX 300 NMR spectrometer using TMS as internal standard and mass spectra on a JEOL JMS600 instrument.

\section{Plant material}

The roots of Piper betle were procured from M/s. United Chemical and Allied Products, Kolkata, India in the month of May 2002 and later authenticated at the Botanical Survey of India, Shibpur, West Bengal. The voucher specimen (DCT-2) was deposited in the laboratory of Department of Chemical Technology, Calcutta University for future reference.

\section{Extraction and Isolation}

Fresh tender roots of $P$. betle (ca. $2 \mathrm{~kg}$ ) were shade-dried and powdered. The pulverised material was then exhaustively extracted in succession under reflux with pet. ether $(2 \times 5 \mathrm{~L}, 6 \mathrm{~h}$ each) and then alcohol ( $2 \times 4.5 \mathrm{~L}, 8 \mathrm{~h}$ each). The pet. ether extract was concentrated in vacuo to yield a reddish-brown mass (15 g), subsequently subjected to column chromatography over Si gel (350 g). Elution with petether and pet. ether-benzene $(4: 1)$ gave stearic acid $(25 \mathrm{mg})$, m.p. $67-68^{\circ} \mathrm{C}$. Elution with 1:1 pet. etherbenzene furnished $\beta$-sitosterol, while pure benzene eluates yielded stigmast-4-en-3,6-dione (1). The alcohol extract was concentrated in vacuo to a brown solid mass (32 g) and then suspended in distilled water ( $c a 200 \mathrm{~mL})$. The aqueous slurry was then extracted successively with ethyl acetate $(3 \times 100$ $\mathrm{mL})$ and water saturated $n$-butanol $(3 \times 150 \mathrm{~mL})$. The organic layers were dried over anhyd. $\mathrm{Na}_{2} \mathrm{SO}_{4}$ and the solvents distilled off in vacuo to yield $12 \mathrm{~g}$ of EtOAc and $17 \mathrm{~g}$ of $n$-butanol extracts, respectively. Column chromatography of the EtOAc extract furnished from the $1: 1 \mathrm{C}_{6} \mathrm{H}_{6}-\mathrm{CHCl}_{3}$ 
eluates an impure brown oily matrix which on repeated chromatography followed by prep. TLC, yielded 2. Subsequent elution with $\mathrm{CHCl}_{3}$ yielded aristololactam A-II (3). The $n$-butanol extract did not give a positive test for saponins.

Stigmast-4-en-3,6-dione (1): Colourless flakes $(28 \mathrm{mg})$ from 4:1 chloroform-alcohol; $\mathrm{R}_{\mathrm{f}} 0.77$ (benzene-ethyl acetate 7:3); m.p. $150-152^{\circ} \mathrm{C}$ (lit.[11] m.p. 156-158 ${ }^{\circ} \mathrm{C}$ ); UV $\lambda_{\max }(\mathrm{MeOH}): 252 \mathrm{~nm}$ $\left(\log \varepsilon\right.$ 4.26); IR $v_{\max }(\mathrm{KBr}) \mathrm{cm}^{-1}: 2920,2840,1675$ ( $\alpha, \beta$-unsaturated ketone), 1455, 1240, 1220; ${ }^{1} \mathrm{H}$ NMR $\left(\mathrm{CDCl}_{3}\right) \delta$ ppm: $0.72(3 \mathrm{H}, \mathrm{s}, \mathrm{Me}-18) ; 0.74-0.95(12 \mathrm{H}, \mathrm{m}, 4 \times \mathrm{Me}) ; 1.16(3 \mathrm{H}, \mathrm{s}, \mathrm{Me}-19)$ and $6.17(1 \mathrm{H}, \mathrm{s}, \mathrm{H}-4)$; EIMS (70 eV) m/z (relative intensity, \%): $426\left(\left[\mathrm{M}^{+}\right], 25\right), 412(9), 411(12), 408$ (10), 398 (11), 384 (7), 285 (30), 275 (13), 257 (10), 243 (25), 229 (13.5), 189 (10), 175 (10), 149 (10), 137 (66), 133 (16), 97 (23), 69 (48), 55 (91).

4-Allyl resorcinol (2): Light brown viscous liquid (12 mg); $\mathrm{R}_{\mathrm{f}} 0.74$ (benzene-ethyl acetate 7:3); UV $\lambda_{\max }(\mathrm{MeOH}) \mathrm{nm}: 241\left(\log \varepsilon\right.$ 3.47), 282 (3.66); IR $v_{\max }$ (thin film) $\mathrm{cm}^{-1}: 3400-3250$ (broad, $\left.-\mathrm{OH}\right)$, 3060, 2950, 2890, $1630(\mathrm{C}=\mathrm{C}), 1600,1520,1400$ (aromatic, $\mathrm{C}=\mathrm{C}$ skeletal in-plane vibration), 1355 (C-O stretching in phenol), 1285, 1200 (-OH bending in phenol), 1115, 970, 865, 815, 790, 760; ${ }^{1} \mathrm{H}-$ NMR $\left(\mathrm{CDCl}_{3}\right) \delta$ ppm: $3.25\left(2 \mathrm{H}, \mathrm{d}, J=9 \mathrm{~Hz},-\mathrm{C}_{2}-\mathrm{CH}=\mathrm{CH}_{2}\right), 5.05\left(2 \mathrm{H}, \mathrm{m},-\mathrm{CH}=\mathrm{C} \underline{H}_{2}\right), 5.69(2 \mathrm{H}, \mathrm{br}$ $\mathrm{s}, 2 \times \mathrm{ArO} \underline{H}), 5.91\left(1 \mathrm{H}, \mathrm{m},-\mathrm{C} \underline{H}=\mathrm{CH}_{2}\right), 6.61(1 \mathrm{H}, \mathrm{dd}, J=9,1.8 \mathrm{~Hz}, \mathrm{H}-6), 6.70(1 \mathrm{H}, \mathrm{d}, J=1.8 \mathrm{~Hz}, \mathrm{H}-$ 2) and $6.78(1 \mathrm{H}, \mathrm{d}, J=9 \mathrm{~Hz}, \mathrm{H}-5)$; EIMS $m / z$ (relative intensity): 150 ([M] $\left.]^{+}, 86\right), 123$ (100), 95 (56), 67 (43). Unavailability of an authentic sample, however, precluded direct comparison.

Aristololactam A-II (3): Pale yellow amorphous solid from benzene (45 mg); $\mathrm{R}_{\mathrm{f}} 0.43$ (benzene- ethyl acetate 1:1); m.p. $260-262^{\circ} \mathrm{C}$; UV: $\lambda_{\max }(\mathrm{MeOH}) \mathrm{nm}(\log \varepsilon): 382(3.66), 364$ (3.68), 341 (3.80), 327 (3.79), 287 (4.27), 277 (4.33), 265 (4.25), 209 (4.54); (+ NaOAc): 385 (3.69), 367 (3.66), 307 (4.04), 288 (4.22), 278 (4.19), 264 (4.15), 212 (4.60); (+2N NaOH): 398 (4.03), 369 (3.99), 307 (4.36), 291 (4.37), 220 (4.68); IR $v_{\max }(\mathrm{KBr}) \mathrm{cm}^{-1}: 3425,1675(\mathrm{C}=\mathrm{O}), 1620,1500,1455,1415,1365,1325,1290$, 1270, 1230, 1195, 1120, 1060, 1035, 890, 875, 835, 735, 690; ${ }^{1} \mathrm{H}-\mathrm{NMR}:\left(\mathrm{DMSO}-d_{6}\right) \delta \mathrm{ppm}: 4.04(3 \mathrm{H}$, s, 10-OMe), 7.12 (1H, s, H-5), 7.54 (2H, m, H-2 and H-3), $7.76(1 \mathrm{H}, \mathrm{s}, \mathrm{H}-8), 7.93(1 \mathrm{H}, \mathrm{m}, \mathrm{H}-4), 9.27$ $(1 \mathrm{H}, \mathrm{m}, \mathrm{H}-1), 10.19\left(1 \mathrm{H}, \mathrm{s}, \mathrm{D}_{2} \mathrm{O}\right.$ exchangeable, $\left.-\mathrm{OH}\right)$ and $10.63\left(1 \mathrm{H}\right.$, br s, $\mathrm{D}_{2} \mathrm{O}$ exchangeable, $\left.-\mathrm{NH}\right)$; EIMS (70 eV) m/z (relative intensity, \%): 265 ([ $\left.\left.\mathrm{M}^{+}\right], 100\right), 250$ (55), 222 (28), 166 (34), 150 (7), 139 (21), 133 (8), 105 (7), 83 (8), 69 (12), 60 (9), 55 (13), 44 (18).

\section{Oxidation of $\beta$-sitosterol with Jones reagent}

To a solution of $\beta$-sitosterol $(100 \mathrm{mg})$ in acetone $(40 \mathrm{~mL})$, Jones reagent [17] $(0.3 \mathrm{~mL})$ was added dropwise with vigorous stirring at room temperature. Upon complete addition of the reagent, the reaction mixture was stirred for an additional $15 \mathrm{~min}$. Excess reagent was destroyed with isopropyl alcohol, water $(50 \mathrm{~mL})$ was added and the product was extracted with ethyl acetate $(2 \times 20 \mathrm{~mL})$. The combined organic layers were washed with saturated sodium bicarbonate $(3 \times 10 \mathrm{~mL})$, distilled water $(2 \times 10 \mathrm{~mL})$ and then dried over anhydrous $\mathrm{Na}_{2} \mathrm{SO}_{4}$. Evaporation of the solvent left a semi-solid which was column chromatographed over Si gel. Elution of the column with 30-50\% benzene in pet. ether yielded stigmast-4-en-3-one (20 mg), m.p. $95-97^{\circ} \mathrm{C}$, followed by 1 (22 mg), m.p. $153-155^{\circ} \mathrm{C} ; \lambda_{\max }$ $(\mathrm{MeOH}): 250 \mathrm{~nm}\left(\log \varepsilon\right.$ 4.20); $v_{\max }(\mathrm{KBr}) 2930,1675 \mathrm{~cm}^{-1}$. 


\section{References}

1. The Wealth of India: Raw Materials; Publications and Information Directorate, CSIR: New Delhi, 1969; Vol. VIII, pp. 84-94.

2. Kirtikar, K.R.; Basu, B.D. Indian Medicinal Plants, 2nd ed.; Bishen Singh Mahendra Pal Singh: Dehradun, India, 1998; Vol. III, pp. 2131-2133.

3. Baslas, R.K.; Baslas, K.K. Chemistry of Indian essential oils - Part VIII. Flavour Ind. 1970, 1, 473-474; [Chem. Abstr. 1971, 74, 34538z].

4. Rastogi, R.P.; Mehrotra, B.N. Compendium of Indian Medicinal Plants, Vol. 3; Publications and Information Directorate: New Delhi, 1993; pp. 502-503.

5. Sarkar, M.; Gangopadhyay, P.; Basak, B.; Chakrabarty, K.; Banerji, J.; Adhikary, P.; Chatterjee, A. The reversible antifertility effect of Piper betle Linn. on Swiss albino male mice. Contraception 2000, 62, 271-274.

6. Adhikary, P.; Banerji, J.; Chowdhury, D.; Das, A.K.; Deb, C.C.; Mukherjee, S.R.; Chatterjee, A. Antifertility effect of Piper betle Linn. extract on ovary and testis of albino rats. Indian J. Exp. Biol. 1989, 27, 868-870.

7. Adhikary, P.; Chowdhury, D.; Banerji, J.; Chatterjee, A. Antifertility effect of crude alcoholic extract of Piper betle stalk. Ind. J. Physiol. Allied Sci. 1998, 52, 22-27.

8. Parmar, V.S.; Jain, S.C.; Gupta, S.; Talwar, S.; Rajwanshi, V.K.; Kumar R.; Azim, A.; Malhotra, S.; Kumar, N.; Jain, R.; Sharma, N.K.; Tyagi, O.D.; Lawrie, S.J.; Errington, W.; Howarth, O.W.; Olsen, C.E.; Singh, S.K.; Wengel, J. Polyphenols and alkaloids from Piper species. Phytochemistry 1998, 49, 1069-1078.

9. Saeed, S. A.; Farnaz, S.; Simjee, R.U.; Malik, A. Triterpenes and $\beta$-sitosterol from Piper betle: isolation, antiplatelet and anti-inflammatory effects. Biochem. Soc. Trans. 1993, 21, 462S.

10. Khosa, R. L.; Singh, R.H. Betel root - an antifertility agent. J. Res. Indian Med. 1972, 7, 65-66.

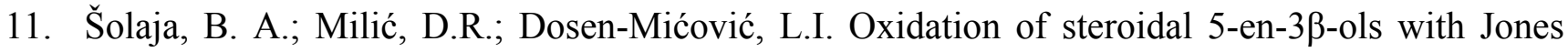
reagent in ether. Steroids 1994, 59, 330-334.

12. Achari, B.; Chakrabarty, S.; Bandyopadhyay, S.; Pakrashi, S.C. A new 4,5-Dioxoaporphine and other constituents of Aristolochia indica. Heterocycles 1982, 19, 1203-1206.

13. Kunitomo, J.; Murakami, Y.; Oshikata, M.; et al. The alkaloids of Stephania sasakii: Structure of five new alkaloids. Phytochemistry 1980, 19, 2735-2739.

14. Castedo, L.; Suau, R.; Mourino, A. A revised structure for pontevedrine. Tetrahedron Lett. 1976, 17, 501-502.

15. Crohare, R.; Priestap, H.A.; Farina, M.; Cedola, M.; Ruveda, E.A. Aristololactams of Aristolochia argentina. Phytochemistry 1974, 13, 1957-1962.

16. Pakrashi, A.; Chakrabarty, B.; Das Gupta, A. Effect of the extracts from Aristolochia indica Linn. on interception in female mice. Experientia 1976, 32, 394-395.

17. Fieser, L. F.; Fieser, M. Reagents for Organic Synthesis; John Wiley and Sons: New York, 1967; Vol. 1, pp. 142-143.

Sample availability: Samples of compounds $1(5 \mathrm{mg})$ and $3(8 \mathrm{mg})$ are available from the authors.

(C) 2005 MDPI (http://www.mdpi.com). Reproduction is permitted for noncommercial purposes. 